\title{
EFFECT OF TESTOSTERONE POLYDIMETHYL- SILOXANE IMPLANTS UPON SPERM PRODUCTION, LIBIDO AND ACCESSORY SEX ORGAN FUNCTION IN RABBITS
}

\author{
L. L. EWING, ${ }^{*}$ L. G. STRATTON† AND C. DESJARDINS $\ddagger$ \\ Department of Physiological Sciences, Oklahoma State University, \\ Stillwater, Oklahoma 74074, U.S.A.
}

(Received 6th October 1972)

\begin{abstract}
Summary. Testosterone-filled polydimethylsiloxane (PDS) capsules $(0.245 \mathrm{~mm}$ wall thickness) were placed subcutaneously in normal adult male rabbits to assess the relationship between the surface area of the implant and the amount of testosterone released. Testosterone release was quantified in terms of plasma testosterone concentrations and other biological endpoints such as libido, accessory sex organ weight, seminal fructose and citric acid levels and spermatogenic activity. Subcutaneous placement of PDS capsules ranging from 100 to $800 \mathrm{~mm}^{2}$ in surface area had no measurable $(P>0.25)$ effect on (1) plasma testosterone concentrations, (2) libido, (3) accessory sex gland weight, and (4) the concentrations of fructose and citric acid in seminal fluid. The total daily sperm production and the number of step- 6 spermatids decreased linearly with each successive increase in capsule surface area. It was concluded that testosterone-filled PDS capsules $\left(800 \mathrm{~mm}^{2}\right)$ induced azoospermia in rabbits without any significant $(P>0.25)$ alteration in either plasma testosterone or the weight and secretory activity of the accessory sex glands.
\end{abstract}

\section{INTRODUCTION}

No systemic method for controlling fertility in human males is at present available (Djerassi, 1970). One potential technique for male contraception involves suppression of spermatogenesis by depressing pituitary gonadotrophin secretion. For example, daily administration of testosterone propionate to human males completely suppressed urinary gonadotrophin excretion within 6 weeks resulting in azoospermia that was reversible upon withdrawal of the hormonal steroid (Heller \& co-authors, 1950). Further use of this technique as

* Present address: Division of Reproductive Biology, Department of Population Dynamics, Johns Hopkins University School of Hygiene and Public Health, 615 N. Wolfe Street, Baltimore, Maryland 21205, U.S.A.

$\dagger$ Present address: Department of Animal Science, University of Arkansas, Fayetteville, Arkansas 72701, U.S.A.

$\ddagger$ Present address: Department of Zoology, The University of Texas, Austin, Texas 78712, U.S.A. 
an effective and practical male contraceptive depends in part upon achieving uninterrupted administration of testosterone at controlled dosages for prolonged time periods. Moreover, before this can be accomplished, it is imperative to demonstrate that antispermatogenic testosterone dosages achieve azoospermia in experimental animals without altering the concentration of plasma testosterone, libido or accessory sex organ function.

Previous results from this laboratory (Stratton, Ewing \& Desjardins, 1971, 1973) indicated that subcutaneous implantation of testosterone-filled polydimethylsiloxane (PDS) capsules offered a promising approach to administering testosterone at controlled rates to both animals and men. In view of this, the present experiments were designed to examine the effects of testosterone-filled PDS implants on circulating testosterone levels, accessory sex gland function, libido and spermatogenesis in adult male rabbits. The results show that subcutaneous placement of testosterone PDS capsules for 3 months induced azoospermia without affecting plasma testosterone concentration, libido or accessory sex organ function.

\section{MATERIALS AND METHODS}

\section{General}

Male rabbits ( $10 \pm 2$ months of age) were supplied by Redwood Game Farm, Salt Lake City, Utah. Rabbits were housed individually in an air-conditioned room on a 14-hr light/10-hr dark schedule and were allowed free access to Purina rabbit chow and water.

Polydimethylsiloxane tubing with wall thickness of $0.245 \mathrm{~mm}$ was obtained from the Dow-Corning Corporation, Midland, Michigan. Capsules of sufficient length to provide surface areas of $100,200,215,400,430$ and $800 \mathrm{~mm}^{2}$ were prepared as described earlier (Stratton et al., 1973). Plasma testosterone levels, libido and accessory sex organ function were measured as outlined previously (Stratton et al., 1973).

\section{Spermatogenic function}

Total daily sperm production was determined by haemocytometer counts of spermatids and spermatozoa in testicular homogenates (Amann \& Lambiase, 1969). For the present study, a known weight of testis was homogenized in $0.85 \% \mathrm{NaCl}$ containing $0.05 \%$ Triton X-100 (Sigma Chemical Company, St Louis, Missouri) in a Waring blender and the spermatids and spermatozoa in the homogenate were counted. Daily sperm production was calculated from testicular spermatid and spermatozoa reserves by using a value of 3.43 as a time divisor (Amann \& Lambiase, 1969).

Testes were fixed in Zenker-formol, dehydrated, embedded in paraffin-wax and transverse sections $(4 \mu \mathrm{m})$ were cut from the mid-portion of the testes. Sections were stained with periodic-acid Schiff and counterstained in haematoxylin (Humason, 1962) to facilitate the identification of the acrosomic system of developing spermatids. Spermatogenesis was quantified by counting all of the germinal cells and Sertoli cell nuclei containing a nucleolus in one (stage VI) of the twelve stages of the cycle of the seminiferous epithelium 
(Desjardins, 1972). Germinal cells at this stage of the cycle consist of type-A spermatogonia, preleptotene and mid-pachytene primary spermatocytes and step-6 spermatids. A total of twenty 'round' tubular cross-sections were counted for each rabbit. Germinal and Sertoli cell counts were corrected for differences in their nuclear diameter by means of Abercrombie's formula (Abercrombie, 1946) as outlined by Clermont \& Harvey (1967) and indices of tubular shrinkage were obtained by dividing the average number of Sertoli cell nuclei per tubular cross-section in control rabbit testes by the corresponding number of Sertoli cell nuclei in testosterone-treated rabbits (Clermont \& Morgentaler, 1955).

\section{Radioimmunoassay of interstitial cell stimulating hormone}

Serum interstitial cell stimulating hormone (ICSH) concentrations were determined according to the double radioimmunoassay procedure described by Scaramuzzi, Blake, Papkoff, Hilliard \& Sawyer (1972). For the present study, parallelism between sera and standards (NIH-LH-S17) was established by repeatedly assaying each sample at several dose levels. Following this, each serum sample was assayed in duplicate at dose levels designed to inhibit the assay between $25 \%$ and $75 \%$. Concentrations of ICSH are expressed as $\mathrm{ng} / \mathrm{ml}$ serum in terms of NIH-LH-Sl and were based on between-assay comparisons. The specificity of the assay was checked by measuring $0 \cdot 1,1$ and $10 \mathrm{ng}$ of standard ICSH in the presence and absence of serum (50,100 and $200 \mu \mathrm{l}$ ) from a hypophysectomized rabbit. Parallel inhibition curves were obtained indicating that serum constituents did not interfere with ICSH measurements. Moreover, assay of ICSH in various dilutions of serum from castrated rabbits produced linear assay curves. Dilution curves of pituitary extracts and serum from male rabbits treated to induce large relative differences in ICSH, TSH and FSH levels were parallel.

\section{Experimental design}

The first experiment was conducted to examine the effects of testosterone PDS implants on spermatogenesis and other androgen-dependent characteristics with implants designed to release either $50 \%$ or the same amount of testosterone produced during a 24-hr period by normal rabbit testes in situ (Goodwin, 1972). Twenty-one male rabbits were trained to ejaculate into an artificial vagina and were allocated to three groups, each consisting of seven animals. These animals received subcutaneous PDS implants as follows: (1) cholesterol-filled $430-\mathrm{mm}^{2}$ capsules, (2) testosterone-filled $215-\mathrm{mm}^{2}$ capsules and (3) testosterone-filled $430-\mathrm{mm}^{2}$ capsules. At 70 days after implantation, sexual behaviour measurements were obtained every other day for 20 days as outlined previously (Stratton et al., 1973). At the end of the 90-day treatment period, the animals were anaesthetized and exsanguinated to obtain blood and tissue samples. One testis from each animal was fixed for histological examination and the remaining testis was weighed, and homogenized as noted above.

A second experiment was performed to examine the effects of varying the surface area of testosterone PDS implants upon spermatogenesis and plasma testosterone concentrations. Thirty intact male rabbits were allocated to five 
treatment groups, each containing six rabbits. One group designated as controls received $400-\mathrm{mm}^{2}$ cholesterol-filled PDS implants. The four experimental groups received 100-, 200-, 400-, and 800- $\mathrm{mm}^{2}$ PDS testosterone-filled implants, respectively. After 90 days, the rabbits were killed to determine body weight, paired testis weight, accessory sex gland weight, plasma testosterone and spermatogenic activity.

\section{Statistical analysis}

The results of both experiments were subjected to a factorial analysis of variance (Snedecor \& Cochran, 1967). When the analysis of variance revealed significant variation, the differences in treatment means were detected by Duncan's Multiple Range Test (Steel \& Torrie, 1960).

\section{Experiment 1}

\section{RESULTS}

Testis weights and total daily sperm production of rabbits receiving $215-\mathrm{mm}^{2}$ and $430-\mathrm{mm}^{2}$ testosterone implants for 90 days were significantly $(P<0.01)$ less than those of control animals receiving cholesterol implants (Table 1).

Table. 1. Average weight of testes and total daily sperm production in rabbits after subcutaneous placement of PDS testosterone implants for 90 days

\begin{tabular}{c|c|c}
\hline $\begin{array}{c}\text { Contents and size } \\
\text { of implants }\end{array}$ & $\begin{array}{c}\text { Paired tesles weight } \\
(\mathrm{g})\end{array}$ & $\begin{array}{c}\text { Total daily sperm } \\
\text { production }\left(\times 10^{6}\right)\end{array}$ \\
\hline Cholesterol; $430 \mathrm{~mm}^{2}$ & $6 \cdot 14 \pm 0 \cdot 61$ & $214.9 \pm 24.4$ \\
Testosterone; $215 \mathrm{~mm}^{2}$ & $3 \cdot 62 \pm 0.38$ & $123 \cdot 5 \pm 29 \cdot 1$ \\
Testosterone; $430 \mathrm{~mm}^{2}$ & $1 \cdot 56 \pm 0.36$ & $16 \cdot 0 \pm 14 \cdot 9$ \\
\hline
\end{tabular}

Each value represents the mean \pm S.E. of seven rabbits.

Moreover, testis weights and total sperm production of rabbits receiving $430-\mathrm{mm}^{2}$ testosterone implants for 90 days were significantly $(P<0.01)$ reduced below those of animals receiving the $215-\mathrm{mm}^{2}$ implants. Five of the seven rabbits containing the $430-\mathrm{mm}^{2}$ testosterone implants were azoospermic. Consequently, the average total daily sperm production figure $\left(16 \times 10^{6}\right)$ for animals receiving the $430-\mathrm{mm}^{2}$ PDS implants may be attributed to two rabbits with impaired but not completely inhibited sperm production (Table 1). The germinal cell counts presented in 'Table 2 confirm that the striking reduction in the total daily sperm production accompanied a change in spermatogenesis. The subcutaneous placement of $215-$ and $430-\mathrm{mm}^{2}$ testosterone implants resulted in proportionate decreases in preleptotene and pachytene spermatocytes and spermatids counted at stage VI of the cycle of the seminiferous epithelium. Although the number of type-A spermatogonia was not influenced by placement of $215-$ and $430-\mathrm{mm}^{2}$ PDS capsules, the number of primary spermatocytes and step-6 spermatids observed after placing $430-\mathrm{mm}^{2}$ implants was significantly $(P>0.01)$ less than that observed after placing $215-$ $\mathrm{mm}^{2}$ implants. 
Partial inhibition of spermatogenesis was attained without altering androgendependent characteristics since no significant $(P>0.25)$ differences were noted in the sexual behaviour scores for intact rabbits receiving cholesterol implants or rabbits receiving $215-\mathrm{mm}^{2}$ and $430-\mathrm{mm}^{2}$ testosterone PDS implants (Table 3 ). Similarly, no significant $(P>0.25)$ differences were detected in the accessory sex organ weight and seminal fructose and citric acid concentrations in intact rabbits receiving cholesterol implants or those receiving 215 - and $430-\mathrm{mm}^{2}$ testosterone PDS implants (Table 3). Most importantly, no significant variation $(P>0.25)$ was observed in plasma testosterone concentrations, the levels averaging $2 \cdot 14 \pm 0 \cdot 75,2 \cdot 74 \pm 1 \cdot 18$ and $2 \cdot 17 \pm 0.9590$ days after subcutaneous placement of $430-\mathrm{mm}^{2}$ cholesterol, $215-\mathrm{mm}^{2}$ and $430-\mathrm{mm}^{2}$ testosterone implants, respectively.

The fact that spermatogenesis was only partially impaired following placement of $215-\mathrm{mm}^{2}$ and $430-\mathrm{mm}^{2}$ PDS capsules suggested the need for a second

Table 2. Effect of testosterone implants in rabbits on the average number of germinal cells per cross-section of seminiferous tubule at stage VI of the cycle of the seminiferous epithelium

\begin{tabular}{l|c|c|c|c}
\hline \multirow{2}{*}{$\begin{array}{c}\text { Capsule contents } \\
\text { and size }\end{array}$} & \multicolumn{4}{|c}{ Germinal cell classification } \\
\cline { 2 - 5 } & $\begin{array}{c}\text { Type-A } \\
\text { spermatogonia }\end{array}$ & $\begin{array}{c}\text { Preleptotene } \\
\text { spermatocytes }\end{array}$ & $\begin{array}{c}\text { Pachytene } \\
\text { spermatocytes }\end{array}$ & $\begin{array}{c}\text { Step-6 } \\
\text { spermatids }\end{array}$ \\
\hline Cholesterol; $430 \mathrm{~mm}^{2}$ & $1 \cdot 1 \pm 0 \cdot 1$ & $15 \cdot 8 \pm 0 \cdot 3$ & $16 \cdot 4 \pm 0 \cdot 3$ & $68 \cdot 5 \pm 2 \cdot 1$ \\
Testosterone; $215 \mathrm{~mm}^{2}$ & $0 \cdot 8 \pm 0 \cdot 1$ & $11 \cdot 4 \pm 0 \cdot 2$ & $1 \cdot 5 \pm 0 \cdot 3$ & $46.9 \pm 3 \cdot 4$ \\
Testosterone; $430 \mathrm{~mm}^{2}$ & $1 \cdot 0 \pm 0 \cdot 1$ & $7 \cdot 1 \pm 0 \cdot 2$ & $7 \cdot 6 \pm 0 \cdot 3$ & $22 \cdot 8 \pm 6 \cdot 1$ \\
\hline
\end{tabular}

Each value represents the average number of cells $\pm S$.E. in twenty tubular cross-sections at stage VI of the cycle of seminiferous epithelium from six rabbits. Cell counts were corrected for differences in nuclear diameters by the formula of Abercrombie (1946) and for tubular shrinkage by a Sertoli cell correcting factor.

experiment designed to elucidate the specific dimensions of testosterone PDS capsules required to render all animals azoospermic without causing hypertrophy of accessory sex organs.

\section{Experiment 2}

The results in Table 4 show that paired testis weights and total daily sperm production decreased significantly $(P<0 \cdot 01)$ as the surface area of testosterone PDS implants was increased from 100 to $800 \mathrm{~mm}^{2}$. All animals receiving the $800-\mathrm{mm}^{2}$ testosterone PDS implants were azoospermic. The data in Table 5 show that the above results reflected a reduction in spermatogenesis. The seminiferous tubules of animals receiving the $800-\mathrm{mm}^{2}$ PDS testosterone implant were devoid of pachytene spermatocytes and step- 6 spermatids. Moreover, the absence of these germinal cells was associated with a striking reduction in the number of preleptotene spermatocytes and type-A spermatogonia. Azoospermia was achieved in all rabbits receiving implants of $800-\mathrm{mm}^{2}$ PDS capsules despite the fact that no significant differences $(P>0 \cdot 25)$ were observed in plasma testosterone concentration in animals receiving the 400$\mathrm{mm}^{2}$ cholesterol PDS implants or those receiving tcstosterone PDS implants 


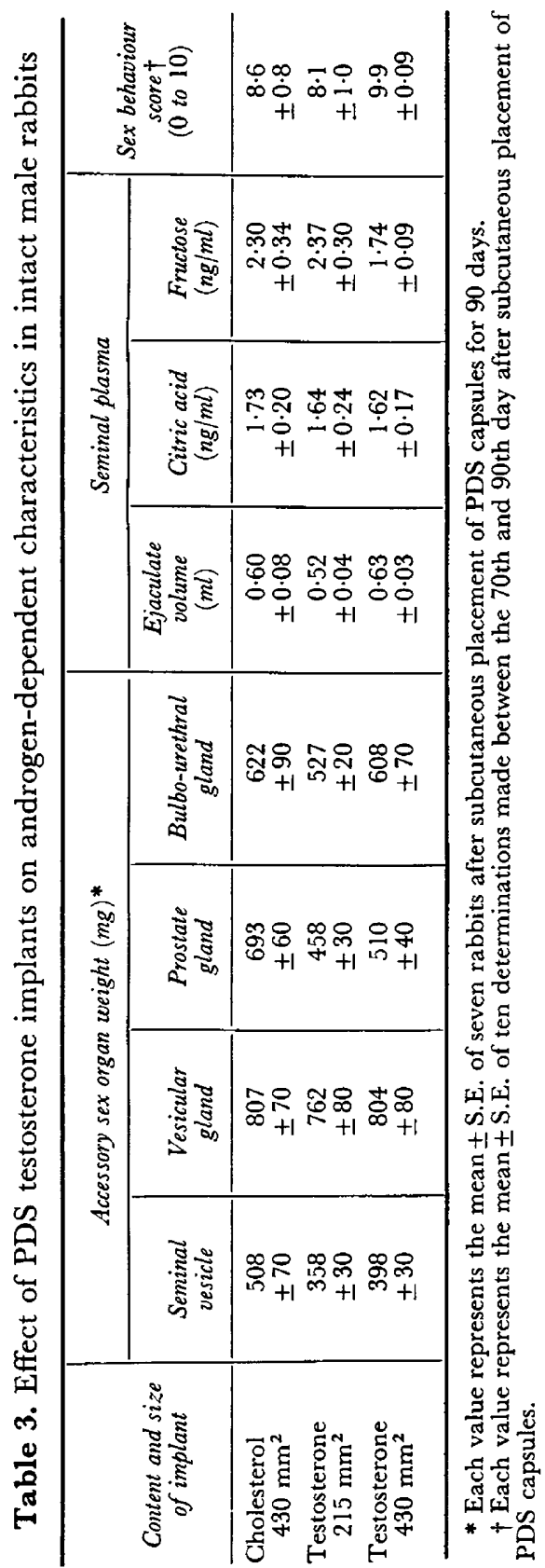


Table 4. Effect of PDS testosterone implants on testis function in rabbits

\begin{tabular}{c|c|c|c}
\hline $\begin{array}{c}\text { Content and size } \\
\text { of implants }\end{array}$ & $\begin{array}{c}\text { Paired testes } \\
\text { weight }(\mathrm{g})\end{array}$ & $\begin{array}{c}\text { Total daily sperm } \\
\text { production }\left(\times 10^{6}\right)\end{array}$ & $\begin{array}{c}\text { Peripheral } \\
\text { testosterone levels } \\
(\mathrm{ng} / \mathrm{ml} \text { blood plasma) }\end{array}$ \\
\hline Cholesterol; $400 \mathrm{~mm}^{2}$ & $4 \cdot 9 \pm 0.6$ & $210 \pm 38$ & $2 \cdot 04 \pm 0.46$ \\
Testosterone; $100 \mathrm{~mm}^{2}$ & $4.8 \pm 0 \cdot 2$ & $193 \pm 17$ & $2 \cdot 01 \pm 1 \cdot 10$ \\
Testosterone; $200 \mathrm{~mm}^{2}$ & $4 \cdot 5 \pm 0.6$ & $154 \pm 36$ & $2 \cdot 02 \pm 0.41$ \\
Testosterone; $400 \mathrm{~mm}^{2}$ & $1 \cdot 9 \pm 0 \cdot 6$ & $34 \pm 19$ & $1.99 \pm 0.41$ \\
Testosterone; $800 \mathrm{~mm}^{2}$ & $0.6 \pm 0.1$ & $0 \pm 0$ & $2 \cdot 02 \pm 0.52$ \\
\hline
\end{tabular}

Each value represents the mean \pm S.E. of six rabbits following subcutaneous placement of PDS capsules for 90 days.

Table 5. Effect of testosterone implants in rabbits on the number of germinal cells per cross-section of seminiferous tubule at stage VI of the cycle of the seminiferous epithelium

\begin{tabular}{c|c|c|c|c}
\hline \multirow{2}{*}{$\begin{array}{c}\text { Content and size } \\
\text { of implants }\end{array}$} & \multicolumn{4}{|c}{ Germinal cell classification } \\
\cline { 2 - 5 } & $\begin{array}{c}\text { Type-A } \\
\text { spermatogonia }\end{array}$ & $\begin{array}{c}\text { Preleptotene } \\
\text { spermatocytes }\end{array}$ & $\begin{array}{c}\text { Pachytene } \\
\text { spermatocytes }\end{array}$ & $\begin{array}{c}\text { Step-6 } \\
\text { spermatids }\end{array}$ \\
\hline Cholesterol; $400 \mathrm{~mm}^{2}$ & $1 \cdot 2$ & $14 \cdot 0$ & $18 \cdot 0$ & $62 \cdot 0$ \\
Testosterone; $800 \mathrm{~mm}^{2}$ & 0.4 & 0.3 & 0 & 0 \\
\hline
\end{tabular}

Each value represents the average number of cells in twenty tubular cross-sections at stage VI of the cycle of seminiferous epithelium from six rabbits. Cell counts were corrected for differences in nuclear diameter by the formula of Abercrombie (1946) and for tubular shrinkage by a Sertoli cell correcting factor.

Table 6. Effect of PDS testosterone implants on the weights of accessory sex organs of intact rabbits

\begin{tabular}{|c|c|c|c|c|}
\hline \multirow{2}{*}{$\begin{array}{c}\text { Content and size } \\
\text { of implants }\end{array}$} & \multicolumn{4}{|c|}{ Organ weights ( $\mathrm{mg})$} \\
\hline & $\begin{array}{c}\text { Seminal } \\
\text { vesicles }\end{array}$ & $\begin{array}{l}\text { Prostate } \\
\text { gland }\end{array}$ & $\begin{array}{l}\text { Vesicular } \\
\text { gland }\end{array}$ & $\begin{array}{l}\text { Bulbo-urethral } \\
\text { gland }\end{array}$ \\
\hline $\begin{array}{l}\text { Cholesterol; } 400 \mathrm{~mm}^{2} \\
\text { Testosterone; } 100 \mathrm{~mm}^{2} \\
\text { Testosterone; } 200 \mathrm{~mm}^{2} \\
\text { Testosterone; } 400 \mathrm{~mm}^{2} \\
\text { Testosterone; } 800 \mathrm{~mm}^{2}\end{array}$ & $\begin{array}{l}312 \pm 47 \\
306 \pm 33 \\
388 \pm 47 \\
311 \pm 47 \\
375 \pm 60\end{array}$ & $\begin{array}{l}611 \pm 68 \\
741 \pm 163 \\
638 \pm 57 \\
479 \pm 41 \\
606 \pm 70\end{array}$ & $\begin{array}{l}642 \pm 60 \\
788 \pm 77 \\
652 \pm 93 \\
565 \pm 68 \\
710 \pm 50\end{array}$ & $\begin{array}{l}663 \pm 173 \\
620 \pm 51 \\
569 \pm 72 \\
484 \pm 54 \\
705 \pm 130\end{array}$ \\
\hline
\end{tabular}

Each value represents the mean \pm S.E. of six rabbits following subcutaneous placement of PDS capsules for 90 days.

varying from 100 to $800 \mathrm{~mm}^{2}$ (Table 4). In parallel with the finding that plasma testosterone levels remained unchanged, the results in Table 6 show that seminal vesicle, prostate, vesicular and bulbo-urethral gland weights were not significantly $(P>0.25)$ altered by increasing surface area of testosterone PDS implants. 


\section{DISCUSSION}

Previous studies (Stratton et al., 1973) indicated that testosterone was released from subcutaneous PDS implants at a relatively uniform and predictable rate, implying that capsules could be designed to mimic testosterone secretion in vivo. The present results demonstrate, for the first time, that subcutaneous implantation of PDS capsules designed to release either $50 \%$ or the same amount of testosterone as that secreted by normal rabbit testes impaired spermatogenesis without influencing the plasma testosterone levels. Other indices of androgen secretion such as sex behaviour and accessory sex organ function were indistinguishable from those of intact rabbits receiving PDS implants containing cholesterol. The failure to observe differences in the concentration of plasma testosterone in animals implanted with 215- and $430-\mathrm{mm}^{2}$ PDS capsules may be attributed to a partial impairment in testosterone secretion in the case of animals receiving the smaller implant. This speculation was supported by the finding that sperm production and testis weight were significantly $(P<0.01)$ higher in animals receiving the $215-\mathrm{mm}^{2}$ implant than in those receiving the $430-\mathrm{mm}^{2}$ capsules. It seems reasonable to suggest that hypophysial gonadotrophin secretion was suppressed further in animals receiving the $430-\mathrm{mm}^{2}$ implants than those receiving the $215-\mathrm{mm}^{2}$ implants since the larger implant was designed to release the same amount of testosterone as that produced by rabbit testes in vivo.

Although neither treatment (i.e. 215 or $430 \mathrm{~mm}^{2}$ ) induced azoospermia in all animals, further examination of testosterone PDS implants over a wide range of surface areas $\left(100\right.$ to $\left.800 \mathrm{~mm}^{2}\right)$ demonstrated that subcutaneous placement of PDS capsules caused a sequential decrease in testis weight and total daily sperm production with azoospermia noted in all animals receiving the $800-\mathrm{mm}^{2}$ capsules. Moreover, implantation of testosterone-filled PDS capsules ranging from 100 to $800 \mathrm{~mm}^{2}$ resulted in plasma testosterone concentrations that were indistinguishable from those of control rabbits. The finding that accessory sex organs were maintained at weights similar to those of control rabbits provides biological support for the observation that plasma testosterone concentrations were similar to those found in intact controls. This finding, taken with the observation that serum ICSH concentrations were undetectable in those rabbits receiving 200-, 400- and $800-\mathrm{mm}^{2}$ PDS implants, suggests that endogenous testosterone production declined with successive amounts of testosterone administered in PDS implants, and that decreased spermatogenesis was due to decreased pituitary secretion of gonadotrophins.

Subsequent investigations in our laboratory of PDS testosterone implants affording surface areas of 1600 to $25,000 \mathrm{~mm}^{2}$ have shown concomitant increases in plasma testosterone concentration, spermatogenesis and accessory sex organ size. These findings suggest that once endogenous testosterone production (and pituitary gonadotrophic hormone secretion) is eliminated, increases in implant surface area result in increased plasma testosterone concentrations in intact rabbits.

Although the results of this investigation demonstrate the feasibility of 
creating azoospermia without elevating plasma testosterone concentrations in rabbits, extension of these findings to man must await further experimentation. For example, spermatogenesis was completely suppressed in 5-kg rabbits with two testosterone PDS implants that were $9 \mathrm{~cm}$ long and $0.2 \mathrm{~cm}$ in diameter. Based on 24-hr testosterone production rates in man (Southern, Tochimoto, Carmody \& Isurugi, 1965), we estimate that thirty to forty such implants filled with testosterone would be required to achieve similar results in a 70-kg man. Since practical considerations make this number prohibitive, it becomes imperative to investigate the effects of PDS implants filled with slowly metabolized testosterone derivatives in experimental animals.

\section{AGKNOWLEDGMENTS}

The authors wish to acknowledge the technical assistance of Mr Robert Amey, Mr John Osborne, Mr Aron Tallent and Mr Paul Will. This investigation was supported in part by U.S. Public Health Service Research Contract 70-2152 and research grants HD-04578 and HD-05795 from the National Institute of Child Health and Human Development and in part by U.S. Public Health Service General Research Support Grant FR-5567. One of us (L.G.S.) was a U.S. Public Health Service Postdoctoral Trainee supported by Training Grant GM-1119; L.L.E. is a recipient of a U.S. Public Health Service Research Career Development Award HD-39926.

\section{REFERENGES}

Abercrombie, M. (1946) Estimation of nuclear population from microtome sections. Anat. Rec. 94, 238. Amann, R. P. \& Lambiase, J. T. (1969) The male rabbit. III. Determination of daily sperm production by means of testicular homogenates. F. Anim. Sci. 28, 369.

Ci.ermont, Y. \& Harvey, S. C. (1967) Effects of hormones on spermatogenesis in the rat. Ciba Fdn Colloq. Endocr. 16, 173.

Glermont, Y. \& Morgentaler, H. (1955) Quantitative study of spermatogenesis in the hypophysectomized rat. Endocrinology, 57, 369.

Desjardins, C. (1972) Spermiogenesis and the cycle of the seminiferous epithelium in the rabbit. Anat. Rec. 172, 301.

DJerassi, C. (1970) Birth control after 1984. Science, N.Y. 169, 941.

Goodwin, D. E. (1972) The effect of growth hormone on testosterone secretion in perfused rabbit testes. Ph.D. thesis, Oklahoma State University.

Heller, G. G., Nelson, W. O., Hill, I. B., Henderson, E., Madlock, W. O., Jungck, E. G., PaulSEN, G. A. \& Mortimore, G. E. (1950) Improvement in spermatogenesis following depression of the human testis with testosterone. Fert. Steril. 1, 415.

Humason, G. L. (1962) Animal tissue techniques, p. 304. W. H. Freeman, San Francisco.

Scaramuzzi, R. J., Blake, C. A., Papkoff, H., Hilliard, J. \& Sawyer, G. H. (1972) Radioimmunoassay of rabbit luteinizing hormone: serum levels during various reproductive states. Endocrinology, 90, 1285.

Snedecor, G. W. \& Cochran, W. G. (1967) Statistical methods, 6th edn. Iowa State University Press, Ames, Iowa.

Southern, A. L., Tochimoto, S., Garmody, N. G. \& Isurugi, K. (1965) Plasma production rates of testosterone in normal adult men and women and in patients with the syndrome of feminizing testes. F. clin. Endocr. Metab. 25, 1441.

Steel, R. G. D. \& Torrie, J. H. (1960) Principles and procedures of statistics. McGraw-Hill, New York.

Stratton, L., Ewing, L. L. \& Desjardins, G. (1971) Testosterone (T) dimethylpolysiloxane (DPS) implants: daily sperm production (DSP), libido and accessory sex organ (ASO) function in male rabbits. Physiologist, Wash. 14, 238.

Stratton, L. G., Ewing, L. L. \& Desjardins, C. (1973) Efficacy of testosterone-filled polydimethylsiloxane implants in maintaining plasma testosterone in rabbits. F. Reprod. Fert. 35, 235. 